Summer 2006

\title{
Separation of Church and State in the United States: Lost in Translation
}

Carol J. Greenhouse

Princeton University

Follow this and additional works at: https://www.repository.law.indiana.edu/ijgls

Part of the Constitutional Law Commons, and the Religion Law Commons

\section{Recommended Citation}

Greenhouse, Carol J. (2006) "Separation of Church and State in the United States: Lost in Translation," Indiana Journal of Global Legal Studies: Vol. 13 : Iss. 2 , Article 7.

Available at: https://www.repository.law.indiana.edu/ijgls/vol13/iss2/7

This Symposium is brought to you for free and open access by the Law School Journals at Digital Repository @ Maurer Law. It has been accepted for inclusion in Indiana Journal of Global Legal Studies by an authorized editor of Digital Repository @ Maurer Law. For more information, please contact rvaughan@indiana.edu.

\section{$\Psi$}

JEROME HALL LAW LIBRARY

INDIANA UNIVERSITY

Maurer School of Law
Blooming ton 


\title{
Separation of Church and State in the United States: Lost in Translation?
}

\author{
Carol J. Greenhouse*
}

\begin{abstract}
In this article, the absence of an American equivalent to the French word laïcité becomes an ethnographic opening to an exploration of the church-state divide in the U.S. context. Drawing on classic social theory, sociological accounts, and current events, I suggest that the constitutional separation of church and state-in addition to whatever it may mean in legal terms-also expresses a cultural proposition. Specifically, the separation of church and state posits a dual role for local communities as both the source of federal power (through representative government) and the foundation of its moral authority. The latter role can be sustained only to the extent that moral community is conceptualized as "outside" the state, extending to the state solely through the democratic process. The article concludes with a reflection on the politicization of "moral values" in the 2004 presidential election.
\end{abstract}

\section{INTRODUCTION}

Why is it that the French word laïcite has no vernacular translation in English? Secular or lay come close, but neither is quite right-both are too "church-minded." In the case of the United Kingdom, the absence of translation is perhaps more easily accounted for in the fact that the monarch is also head of the Church of England-the historical legacy of a direct royal challenge to papal sovereignty. In the United States, the constitutional separation of church and state repeats this challenge by generalizing its elements: The separation of church and state is not only a warrant for religious liberty, but also a bar against church-based claims to authority in the state arena. It is also more than this.

*Professor, Department of Anthropology, Princeton University. A.B. (Anthropology) 1971, Ph.D. (Social Anthropology) 1976, Harvard University. My thanks to Elisabeth Zoller, Alfred Aman, and the other participants of the conference on "La Conception Américaine de la Laïcité" at the Université Paris II (Panthéon-Assas), where I presented this paper on January 28, 2005. 
My purpose in these remarks is not to ask the historical question of how the constitutional protections of religious liberty and church-state separation came to take the forms they did. Rather, I consider the connections between religion and political legitimacy as an interpretive problem in the ethnographic sense. To state the ethnographic issue more concretely: The church-state divide in the United States involves more than a legal doctrine concerned with individual liberty. It is also deeply inscribed in institutional forms, conventionalized concepts of society, and subjective aspects of citizenship and politics. While I am not prepared to venture onto the inevitably speculative ground of the question "What do Americans believe?," I will suggest that the church-state divide is deeply implicated in the U.S. public sphere in a way that makes laïcité difficult to grasp intuitively from American ground. And so it is not "American culture" that is my subject here, but the resistance of laïcité to American translation.

To begin with some observations: The separation of church and state in the United States does not by itself create a secular state-and even less so, a secular public sphere. On the contrary, the constitutional requirement of separation can be (and is widely) read as a necessary connection between political legitimacy and religious pluralism-a proposition that carries significant if changeable cultural content in the United States today. Ethnographic and sociological accounts of civic, economic, and religious life among Americans return again and again to this connection as a fundamental principle of personal worth (in both the moral and economic sense of this term) and criterion of collective social value.

In short, the problem of translation points to a deeper conundrum of comparing not just legal institutions and processes, but also social institutions and political cultures. In this brief essay, I can do no more than broach these comparative issues, and only from one side.

\section{Lä̈CITÉ AND MoRal LegitimaCY}

Several current debates in the United States make this a timely moment to consider issues such as these-for example, the legal contest over whether the "Pledge of Allegiance" should include the words "under God." In case there are readers who are not familiar with this element of U.S. public culture, I should explain that the pledge is a short credo, an oath of citizenship, commonly pronounced by a group in unison at civic occasions-and especially in elementary 
and secondary schools, as a daily opening ceremony. ${ }^{\prime}$ As in France in the context of the veiling issue, Americans, too, have had longstanding debates over the civic display of religious symbols, the latter particularly associated with the Christmas season (a town hall may erect a Christmas tree but not a nativity scene, for example). The courts have also addressed the religious requirements of a Sabbath and other holidays as an issue in schools and employment, and of religious dress (yarmulkes and turbans, for example) as these entail modifications of military uniforms, among other religious practices. But contests over the protection of religious symbols and practices are only one kind of evidence of the cultural dimensions of the question underlying this conference.

This is also a timely moment from another perspective, in that the presidential elections of 2004 whetted the public appetite (judging by the media, in search of an interpretation of the outcome) for commentary about the values content of political life. Such commentary is relatively diffuse-but it is useful, since it compresses into a single conversational frame issues of political life and (to use the vernacular expression) "moral values." I hear these commentaries as a public conversation about the moral basis of state action. The separation doctrine in itself does not answer the question of how the moral basis of the state should be constituted. Must state action be moral in itself? Or does the moral basis of the state derive from its political legitimacy $?^{3}$ In the process of crafting the rationale for the Civil Rights Act of 1964, for example, Robert Kennedy (then U.S. Attorney General) resisted an overtly moral discourse so as to protect the document from challenge on the basis of exceeding the boundary between state action and private life-opting instead for the Constitution's so-called "Commerce Clause" guaranteeing federal protection for interstate commerce. ${ }^{4}$ Similarly (if sometimes con-

1. The oath is supported by a ritual posture, standing at attention (men's heads bare) with one's right hand over the heart. The text reads: "I pledge allegiance to the flag of the United States of America, and to the republic for which it stands, one nation, under God, indivisible, with liberty and justice for all."

2. Such questions as these are particularly contentious in the United States at the moment. The prevailing "spin" on the most recent presidential election interpreted the outcome as a public endorsement of "moral values" - an untestable proposition for various reasons. See Louis Menand, Permanent Fatal Errors, New Yorker, Dec. 6, 2004, at 54-60. But be that as it may, as of the week after the election, "values" and "issues" had entered common parlance as a representation of contrasting worldviews.

3. For a discussion of legal legitimacy, see Tom R. Tyler \& Gregory Mitchell, Legitimacy and the Empowerment of Discretionary Legal Authority: The United States Supreme Court and Abortion Rights, 43 Duke L.J. 703 (1994).

4. Gerald Gunther \& Kathleen M. Sullivan, Constitutional Law 201-02 (13th ed. 1997). 
versely), contemporary debates over abortion, capital punishment, affirmative action, same-sex marriage, and, now, preemptive war, interrogation of military prisoners, and other issues bearing on security are polarizing precisely because they press the question of whether state action must be moral in itself, or derivative from a democratic process through law-revealing a profound lack of consensus. It is not a coincidence that the most contested issues are those affecting the status of the physical body. For some purposes, the body is the social surface of the state, while for others, it always stands in front of (before) the state. These are not questions to which most Americans have fixed or ready answers, and the lack of consensus reflects not just different religious ideas, but also different ideas about politics, and the nature and limits of federal power through law.

Let us consider these zones of contention, setting aside for the moment questions of specific religious tenets and their legal status, so as to consider how church-state separation works in relation to federal power-purely hypothetically. For some Americans, the state must always "act" morally (as if it were a person); morality in this sense does not derive from the political order, but from the nature of state action in and of itself. For others, the state's moral legitimacy derives from the political process. These are two substantially different politicalmoral worldviews in theory, although they do not necessarily clash as a practical matter.

\section{Religion Otherwise: The Spirit of Capitalism}

In cultural terms, what we call the separation of church and state is perhaps better described as a "divide"-as if they were two slopes connected by a path that can be traveled in either direction. Some of the theoretical resources for exploring this issue derive from the specificities of U.S. experience-most notably Max Weber's influential account of "the Protestant ethic" in American life. Indeed, the centennial of the legislation we are marking in this conference is also the centennial of Weber's classic sociological treatise on religion and "the spirit of capitalism" in the United States-notably The Protestant Ethic and the Spirit of Capitalism and his extended essay, "The Protestant Sects and the Spirit of Capitalism." The latter essay is based in part on Weber's experiences in the United

5. Max Weber, The Protestant Ethic and the Spirit of Capitalism (Talcott Parsons trans., Charles Scribner's Sons 1958) (1905); Max Weber, The Protestant Sects and the Spirit of Capitalism, in From Max Weber: Essays in Sociolocy 302 (H.H. Gerth \& C. Wright Mills trans. \& eds., Oxford Univ. Press 1976) (1906). 
States, in the course of a tour in 1904. His itinerary included a visit with relatives in North Carolina, where he witnessed a rural baptism by immersion, and developed his impressions of American Protestantism based on his observations and informal interviews among his hosts and their acquaintances.

In the course of his travels, Weber was especially impressed with Americans' pervasive "church-mindedness," as measured in terms of both the extent of church membership and tithing, even among the poor. Reflecting on his observations, he writes: "Nobody who visited the United States fifteen or twenty years ago, that is, before the recent Europeanization of the country began, could overlook the very intense church-mindedness which then prevailed in all regions not yet flooded by European immigrants." To this statement he appends a footnote: "The opening by prayer of not only every session of the U.S. Supreme Court but also of every Party Convention has been an annoying ceremonial for quite some time." ${ }^{8}$ But he quickly turns back to the social importance of church membership: "If one looked more closely at the matter in the United States, one could easily see that the question of religious affiliation was almost always posed in social life and in business life which depended on permanent and credit relations." He illustrates this thesis with a vignette, quoting a traveling salesman with whom he had a conversation about American religion: "Sir, for my part everybody may believe or not believe as he pleases; but if I saw a farmer or a businessman not belonging to any church at all, I wouldn't trust him with fifty cents. Why pay me, if he doesn't believe in anything?"'

Church membership followed not just a profession of faith, but also a process of qualification, and, in Weber's view, it was through qualification that church membership came to represent an individual's social worth in a way that simultaneously affirmed his economic credit worthiness. Membership was especially important for a mobile society, since "moving one's letter" (i.e., transferring membership to another congregation) allowed for a transfer of social value in the new community. Moreover, Weber saw church membership as one element in an individual's wider membership in clubs and voluntary associations, clubs being essential to the personal transformation promised by the cult of the "self-made man." "In America," Weber writes, "mere 'money' in itself ... purchases power, but not social honor... [and] the old tradition respected the selfmade man more than the heir.... [T] he specifically American democracy...

6. The Protestant Sects and the Spirit of Capitalism, supra note 5, at 302.

7. Id. at 302-03.

8. $I$ d. at 303 n.*.

9. Id. at 303 . 
[does] not constitute a formless sand heap of individuals, but rather a buzzing complex of strictly exclusive, yet voluntary associations." 10

Churches as clubs (whatever else they may be for individuals in terms of faith) were the successors to their earlier importance as civic associations-as political associations and deliberative bodies, integral to the representative democracy of the early republic. Separation of church and state in that context was a warrant for the democratic foundations of government, in that the churches were guaranteed an independent existence that could not be subsumed into the state. The church community became an arena in which members not only could but had to prove themselves, simultaneously constituting an authoritative collective discipline and a repertoire of confirming signs in more personal terms.

Thus, the prevalence of churches as the primary voluntary association for most Americans had the effect of coloring American society with the "ethos" of Protestant asceticism" - what Weber elsewhere calls "the spirit of capitalism"the "individualist impulse" fused through church membership to the institutional spectrum (personal, social, economic, political) of moral value. ${ }^{2}$ Weber argues that the Puritan origins of the spirit of capitalism remain accessible in the drive to affirm one's identity by material things, valued not in themselves, but as signs of worth-the traces of the idea of religious calling (or vocation) only partially secularized by the conditions of contemporary life. ${ }^{13}$

Weber's thesis is suggestive for our purposes, given the central place he accords church membership as the leading context of association of the private sector, outside of the family and workplace (but also overlapping both of these, as we shall see). More contemporary ethnographic studies of American Protestantism (including my own) tend to confirm the main elements of his thesis-the social value placed on church membership, the ascetic ethos of self-fashioning, the revalorization of capital as a sign of moral value and self-discipline, and the inseparability of economy, society, and politics from the moral community implied by church membership. ${ }^{14}$ Moreover, some of the central forms of American

10. Id. at 310 .

11. Id. at 313 .

12. Id. at $320-22$.

13. See id. at $181-82$.

14. For ethnographic discussion and further references, see generally Patricia Ewick \& Susan S. Silbey, The Common Place of Law: Stories from Everyday Life (1998); Carol J. Greenhouse, Prayinc for Justice: Faith, Hope and Community in an American Town (1986); Carol J. Greenhouse et al., Law and Community in Three American Towns (1994); Sally Engle Merry, Getting Justice and Gettinc Even: Legal Consciousness Among Working-Class 
community life-family reunions (including gender roles within families), assemblies, parades, the significance of narrative (testimony), and the rhetoric of "civil religion"- are the legacy of Protestant ritual forms. ${ }^{15}$ The forms of civic life are by no means produced by a single stamp in the United States or anywhere else. Still, social forms such as these are like archives, preserving local meanings for rereading in the present-and blurring the distinctions between private and public life.

From this perspective, the constitutional separation of church and statewhatever else it may be-is less about religion per se than it is about the nature of community in relation to the problem of democratic government. Most importantly, it specifies local community as moral community, and designates local moral community as the moral basis of the state. Representative government, then, is not just the articulated flow of sovereignty from the people to the state; the church-state divide warrants the source of sovereignty as inexhaustible-in that the moral community cannot be absorbed structurally into the state. To the extent that privatization and new hybrid forms of public-private governance are now prevalent in the United States, Weber's thesis is relevant well past the forms of local governance and investment that occupied his attention at the turn of the last century. The depth of these connections between local community and moral community, and the moral community as the conceptual template for a private sector distinct from the state, constitute one broad set of reasons why laïcité has no vernacular translation in American English.

\section{The State Otherwise: Modern Governmentality}

So far, we have been discussing the church-state divide from the standpoint of the way church membership-the template for a wide array of memberships-supplies crucial forms and meanings to local social life in the United States. I have borrowed from Weber and more contemporary sociological accounts to suggest that, viewed from local ground, the church-state divide is (the-

Americans (1990); Barbara Yngvesson, Virtuous Citizens, Disruptive Subjects: Order and Complaint in a New England Court (1993). See also Lived Religion in America: Toward a History of Practice (David D. Hall ed., 1997).

15. On reunions, pilgrimages, and assemblies, see generally Gwen Kennedy Neville, Kinship and Pilgrimage: Rituals of Reunion in American Protestant Culture (1987); W. Lloyd Warner, The Family of God: A Symbolic Study of Christian Life in America (1961). On "civil religion," see Robert N. Bellah, Civil Religion in America, 96 DaEdalus 1 (1967). 
oretically) a bridge between local moral communities on the one hand, and state and federal power on the other. Let us now turn to the other end of that bridge, to consider, if only briefly, some issues bearing more directly on the nature of the state implied in this arrangement. Here, my focus is solely on the federal government-a major limitation in terms of how the state actually functions, but perhaps less so for purposes of my discussion. Here, too, I want to suggest that the federal government is not merely a structural or institutional arrangement, but also a system of meaning-a discourse, in the Foucauldian sense. One route across this theoretical bridge would be to ask whether and how the federal discourse accommodates the ambiguous exteriority of its moral foundations (as discussed above). I consider two paths in this regard.

Clearly, one path is through the democratic process-conceived as a dynamic hierarchy of democratic arenas, each one representing the one below. Less clear is the extent to which American voters imagine this hierarchy as ideally encompassed by a circuit of personal moral identification - that is, measuring politicians by the same standards one would bring to the choice of a partner or a spouse. For some, consistent with Weber's thesis, this is clearly very importantthe "likeability" factor, to borrow pollsters' argot. For others, it is not important-politics being a job description that should be measured by performance, rather than by the candidate's (or incumbent's) personal character. This has been a frequently recurring theme of American political commentary since 1998, dominating both the 2000 and 2004 presidential elections.

These might be two responses to a situation created by the expansion of the federal state through the civil rights era and through regulatory agencies (during the 1960s and 1970s), and then, in quick succession, the ideological dismantling of "big government" in favor of private forms of regulation-leaving local communities in a sense doubly displaced, first by federal legislation and law enforcement and then by neoliberal privatization. ${ }^{16}$ Particularly for communities inclined to resist the earlier developments, the latter period might have offered ideological but not substantive comfort, since deregulation and retrenchments on civil rights did not return power to local governments. ${ }^{17}$ The attempt to harness federal power to local community norms would seem to be symptomatic of

16. Cf. Jacques Donzelot, The Mobilization of Society, in The Foucault Effect: Studies in Governmentality 169 (Graham Burchell et al. eds., 1991) (examining social democracy and neoliberalization as responses to perceived problems of the "welfare state" in France).

17. Alfred C. Aman, Jr., The Democracy Deficit: Taming Globalization Through Law REFORM 46-47 (2004). 
this structural disappointment, whereas for others, in other subjective political positions, a more managerial outlook could be a meaningful accommodation to changing times. The renaissance of "church-mindedness" (from above) is deeply coded as an appeal to the former structural reaction, and the calls for "traditional moral values" are (whatever else they might yield in terms of substantive legislation) clearly intended as a symbolic warrant for the president's moral fitnessparadoxically expanding the discursive scope for executive power rather than returning it to local communitics. Be that as it may, the relationship between moral identification (through representation) and the structure of the political institutions of government is one path along which the church-state divide surfaces as a structural feature within the state.

The second path, correspondingly, has to do with what Michel Foucault calls "the art of government" or "governmentality." refer to the contexts in which the functions of government are inherent in its form, conceived through (and borrowing the moral legitimacy of) a model of authority worked out elsewhere, in another register. For example, he proposes that while early state governmentality worked through the authority of the family, modern governmentality rests on a break from the family form:

What ... now emerges into prominence is the family considered as an element internal to population, and as a fundamental instrument in its government.... [P]rior to the emergence of population [i.e., the idea of population], it was impossible to conceive the art of government except on the model of the family, in terms of economy conceived as the management of a family; from the moment when, on the contrary, population appears absolutely irreducible to the family, the latter becomes of secondary importance compared to population, as an element internal to population: no longer, that is to say, a model, but a segment. ${ }^{19}$

By this criterion the situation of governmentality in the United States is not fully modern, in Foucault's sense. While the family is privileged as a source of information (as Foucault says is the essence of its role as a segment of government),

18. See generally Michel Foucault, Governmentality, in The Foucault Effect: Studies in GovERNMENTALITY, supra note 16 , at 87.

19. Id. at 99-100. 
it also remains more than that in the United States-not quite a template, not exactly a technology, the family is deeply embedded in the encodings by which the functions of state governing are legible as moral propositions as well as institutional claims to efficacy. Oddly, perhaps, the federal implication of "family values" works both ways-sometimes concealing the state implication in the experience of gender and partnership, for example, but equally concealing the fabric of identifications that makes government creditable in democratic terms.

The indispensability of family to the mutual recognition of state and citizen through social security is evidence of a circuitry of legitimacy that is not wholly contained by either (that is, by state or citizens).

To summarize: I have suggested that the separation of church and state in the United States is more than a legal doctrine protecting individual religious liberty; it is also a cultural proposition as to the moral architecture of the U.S. state. That proposition is structural in character, stipulating the source of the state's moral order as originating in local communities conceived as moral communities - and thereby a component in the federal system of checks and balances. From the interpretive standpoint I have been developing in this essay, the church-state divide is a warrant for both individual liberty and a moral economy only partially vested in state power. It is this structural implication of the church-state divide, not the implication of liberty, that makes laïcité difficult to translate. Since the language of Carl Schmitt has become widely familiar through the administration's rhetoric of "friends" and "enemies" in the international context, I will venture the further observation that Schmitt's first prescription for democracy-overcoming the antithesis between politics and religion-poses similar difficulties of translation into the American context. ${ }^{20}$ In the American context, at least, it is difficult to imagine the elimination of this divide as an advance for democracy, since it is the very thing that most conspicuously renders local communities irreducible-and therefore indispensable - to the moral legitimacy of government, confirmed through political checks.

Should we look for a popular translation of laïcité in some future edition of the Robert-or better yet, Webster's-dictionary? To say yes would mean ignoring historical and sociological specificities in relation to what currently counts as national experience. And yet it is not possible to say no, since future challenges to democracy cannot be known in advance.

20. Carl Schmitt, The Concept of the Political 23, 26 (George Schwab trans., 1996). 